\title{
Variation in soil carbon stock and nutrient content in sand dunes after afforestation by Prosopis juliflora in the Khuzestan province (Iran)
}

\author{
Mostafa Moradi ${ }^{(1)}$, \\ Fatemeh Imani ${ }^{(1)}$, \\ Hamid Reza Naji (2), \\ Sareh Moradi Behbahani ${ }^{(1)}$, \\ Mohammad Taghi Ahmadi (i)
}

\begin{abstract}
Prosopis juliflora is one of the suitable tree species used as vegetation cover for sand dunes fixation. The objectives of this study were to determine the effect of $P$. juliflora afforestation and its canopy coverage classes on soil carbon $(C)$ stock and nutrient status in sand dunes after 22 years since afforestation. We hypothesized that increasing the canopy coverage would result in higher soil $\mathrm{C}$ stocks and nutrient content. We selected two 10-ha afforested sand dunes with $\mathbf{2 5 - 5 0 \%}$ and more than $75 \%$ canopy coverage, respectively, and a 10-ha non-afforested dune (control). At each site, 15 soil samples were taken at two depths $(0-5 \mathrm{~cm}$ and $5-50 \mathrm{~cm})$. The results indicated a strong increase in the topsoil C stock (from 0.54 to $4.49 \mathrm{tC} \mathrm{ha}^{-1}$ in control and afforested sites, respectively), while a lower change in subsoil C stock was detected (3.0 and 4.6 tC ha- in control and afforested sites, respectively). Although, different canopy classes resulted in no significant differences in soil $C$ stock, significant differences were observed for all the soil physico-chemical properties that were studied.
\end{abstract}

\section{Keywords: Canopy Coverage, Carbon Stock, Soil Physico-chemical, C/N Ratio}

successful plantations (Jackson et al. 2005) even though other factors may also play an important role, e.g., plant species (Zhang et al. 2013), stand age (Sariyildiz et al. 2015), and management (Jones \& Donnelly 2004). Prosopis juliflora is known as a species with good performance in arid and semi-arid areas for afforestation (Shackleton et al. 2014) and this species has been planted in several parts of Iran. However, the effects of sand dunes afforestation with $P$. juliflora on soil $C$ and nutrients remain still poorly understood, though some preliminary information about the impacts on soil physico-chemical properties have been previously reported (Kahi et al. 2009).

The objectives of this study were to determine the effect of $P$. juliflora sand dunes afforestation on soil $C$ stocks and the nutrient status of afforested sand dunes. In addition, we determined the variation of soil $\mathrm{C}$ stock and soil physico-chemical prop-
(1) Department of forestry, Faculty of Natural Resources and Environment, Behbahan Khatam Al-Anbia University of Technology (Iran); (2) Department of Forest Sciences, University of Ilam, Ilam (Iran)

@ Mostafa Moradi (moradi4@gmail.com)

Received: Jun 15, 2016 - Accepted: Feb 13, 2017

Citation: Moradi M, Imani F, Naji HR, Moradi Behbahani S, Ahmadi MT (2017). Variation in soil carbon stock and nutrient content in sand dunes after afforestation by Prosopis juliflora in the Khuzestan province (Iran). iForest 10: 585-589. - doi: 10.3832/ifor2137-010 [online 201705-08]

Communicated by: Giorgio Alberti erties under different canopy coverage classes. We hypothesized that increasing the canopy coverage could result in higher soil $C$ stock and nutrient status of sand dunes.

\section{Material and methods}

\section{Study site}

The study site was located towards the south of Susa and north of Ahvaz at latitude $48^{\circ} 17^{\prime} 16^{\prime \prime} \mathrm{N}$ and longitude $31^{\circ} 37^{\prime} 60^{\prime \prime}$ $E$ in Khuzestan province of Iran. This site suffers from active sand dunes mostly covered by Cyperus rotundus, Pennisetum orientallis, Echinops kermanshahanicus and Artemisia vulgaris. The mean annual temperature and mean precipitation at the site are $23{ }^{\circ} \mathrm{C}$ and $251 \mathrm{~mm}$, respectively (Fig. 1); soil can be classified as an Entisol; slopes are between 0 and $2 \%$ and altitude between 25 and $49 \mathrm{~m}$ a.s.l. The site studied was covered by petroleum mulch in 1991 and an afforestation program with Prosopis juliflora started in 1993.

Soil sampling, analysis and carbon stock We selected two afforested sand dunes (10 ha each) with two levels of canopy cover $(25-50 \%$ and $>75 \%$ ) and a nearby nonafforested sand dune (10 ha) as control. Canopy coverage was estimated using a dot grid on aerial photography (Carreiras et al. 2006). At each site fifty $20 \times 20 \mathrm{~m}$ quadrat plots were randomly selected (Baldeck et al. 2013) and five soil samples from four corners and the centre of each plot were taken in April 2015 using a manual auger. The five soil sub-samples were pooled by depth $(0-5$ and $5-50 \mathrm{~cm}$ ) and 
Fig. 1 - Location of the study site and different canopy coverage classes (A: canopy coverage of 25-50\%; B: More than

$75 \%$ canopy coverage; C: control dunes).

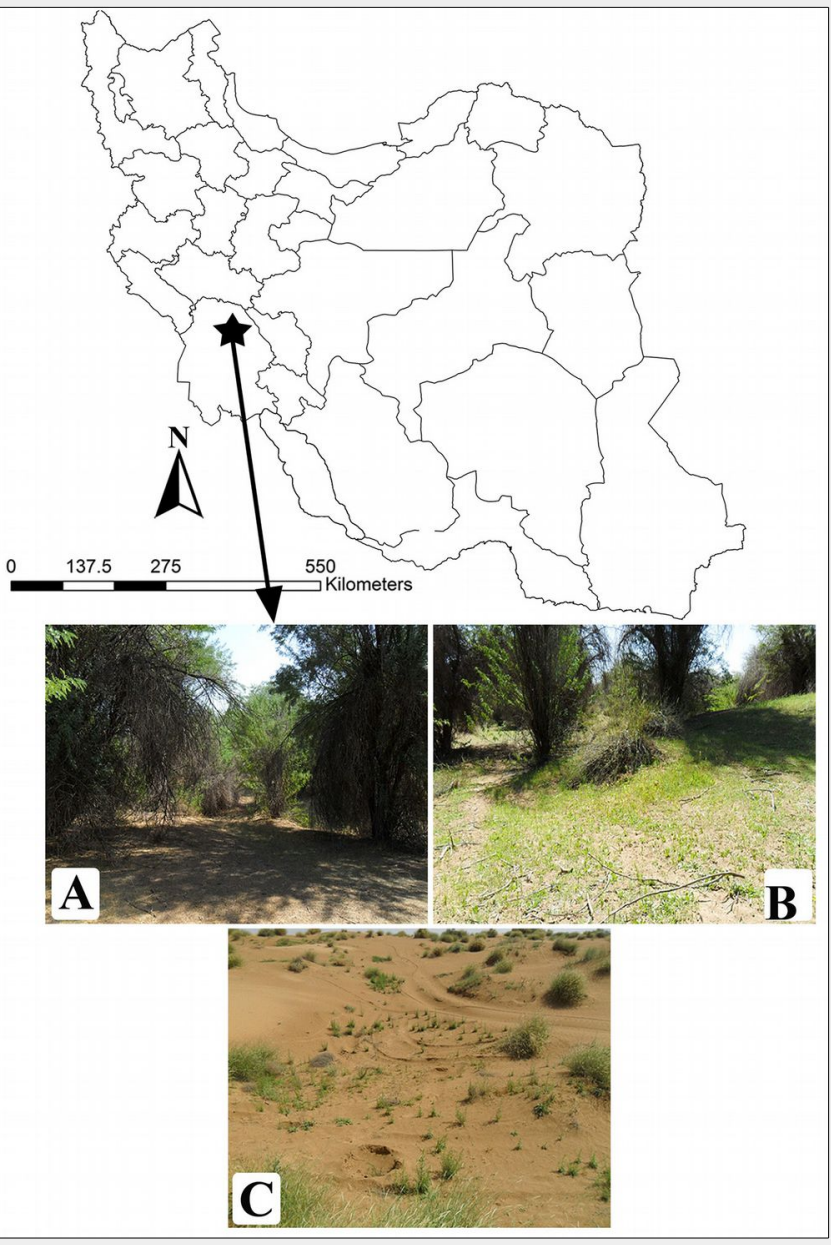

plot, and then transferred to the laboratory for the further analyses. The soil $C$ stock (Cs, tC ha-1) was computed using the following equation (Stringer et al. 2015 eqn. 1):

$$
C s=B d \cdot d \cdot C
$$

where $B d$ is the soil bulk density $\left(\mathrm{g} \mathrm{cm}^{-3}\right)$, texture was defined using the hydrometric method (Houba et al. 1995). Soil pH and electrical conductivity $(\mathrm{EC})$ in deionized water were measured using the method proposed by McLean (1982).

\section{Statistical analysis}

The data were checked for normality and homogeneity of variance using the Kolmogorov-Smirnov test and the Levene's test, respectively. Differences in soil C stock and soil physico-chemical properties between afforested sites and control were tested using a two-way ANOVA followed by LSD test. In addition, Pearson's correlation analysis was used to detect relationships between soil $C$ stock and physicochemical properties. All analysis were performed using the software SPSS ${ }^{\oplus}$ ver. 15 (IBM, Armonk, NY, USA) for Windows ${ }^{\circledR}$.

\section{Results}

\section{Soil physico-chemical properties}

Our result indicated that the interactions between soil depth and canopy classes are significant for soil $\mathrm{C}$ stock and physicochemical properties. The soil texture at a depth of $0-5 \mathrm{~cm}$ in the afforestation and control site were respectively sandy-loam and sandy. The soil texture at 5-50 cm was sandy in both the afforestation and control sites. A significant increase of $44 \%$ was observed in topsoil $(0-5 \mathrm{~cm})$ silt percentage in afforestation compared to control sites. No significant differences in silt percentage were observed between sites at 5-50 cm depth (Tab. 1). Soil EC was significantly affected by both canopy cover classes and soil depth. The lowest EC value belonged to control dunes, followed by $25-50 \%$ canopy coverage and next 75 \% canopy coverage (Tab. 1). Soil pH was significantly decreased in afforestation sites compared to the control dune (Tab. 1). In the afforestation sites, soil $P$ was significantly

Tab. 1 - The ANOVA for soil physico-chemical properties in studied afforestation, control dunes and soil depth. Values followed by the same letters were not significantly different ( $p>0.05$ ) within rows after LSD test. Values are means \pm SE.

\begin{tabular}{|c|c|c|c|c|c|c|c|c|}
\hline Canopy Cover & $25-50 \%$ & & $>75 \%$ & & Control & & & \\
\hline Soil depth & $0-5 \mathrm{~cm}$ & $5-50 \mathrm{~cm}$ & $0-5 \mathrm{~cm}$ & $5-50 \mathrm{~cm}$ & $0-5 \mathrm{~cm}$ & $5-50 \mathrm{~cm}$ & & \\
\hline Silt (\%) & $10.00 \pm 0.65^{a}$ & $6.00 \pm 0.30^{b c}$ & $10.13 \pm 0.66^{a}$ & $5.07 \pm 0.20^{c}$ & $6.53 \pm 0.29^{b}$ & $5.73 \pm 0.12^{\mathrm{bc}}$ & 27.25 & 0.001 \\
\hline & $90.00 \pm 0.65^{c}$ & $94.00 \pm 0.30 \mathrm{ab}$ & $89.87 \pm 0.66^{c}$ & $94.93 \pm 0.20^{a}$ & $93.47 \pm 0.29^{b}$ & $94.27 \pm 0.12^{\mathrm{ab}}$ & 7.25 & 0.001 \\
\hline $\mathrm{EC}(\mathrm{c}$ & $.07^{\mathrm{a}}$ & $0.81 \pm$ & $1.01 \pm 0.06^{a}$ & $0.66 \pm 0.02^{c}$ & $0.40 \pm 0.01^{d}$ & $0.25 \pm 0.01^{\mathrm{e}}$ & 47.31 & 0.001 \\
\hline $\mathrm{pH}$ & $05^{d}$ & $7.89 \pm 0.09^{b}$ & $7.63 \pm 0.09^{c}$ & $7.99 \pm 0.10 \mathrm{ab}$ & $.08^{\mathrm{ab}}$ & & 34 & 0.001 \\
\hline & 14.07 & $2.79 \pm 0.020^{b}$ & 10.2 & 3.82 & $0.04^{c}$ & $0.06^{c}$ & 20.91 & 0.001 \\
\hline & 216.33 & $200.07 \pm 10.48^{\mathrm{ab}}$ & $170.00 \pm 14.44^{b}$ & $130.67 \pm$ & $09.00 \pm$ & $124.60 \pm$ & 14.88 & 0.001 \\
\hline $\mathrm{N} \%$ & $0.04 \pm 0.00^{b}$ & $0.04 \pm 0.01^{b}$ & $0.06 \pm 0.00^{a}$ & $0.04 \pm 0.01^{b}$ & $0.02 \pm 0.00^{c}$ & $0.03 \pm 0.00^{b c}$ & 4.42 & 0.001 \\
\hline
\end{tabular}

Tab. 2 - The ANOVA for carbon stock and $C / N$ in afforestation, control sand dunes and soil depth. Values followed by the same let ters were not significantly different $(p>0.05)$ within rows after LSD test. Values are means \pm SE.

\begin{tabular}{|c|c|c|c|c|c|c|c|c|}
\hline Canopy Cover & $25-50 \%$ & & $>75 \%$ & & Control & & F- & P- \\
\hline Soil depth & $0-5 \mathrm{~cm}$ & $5-50 \mathrm{~cm}$ & $0-5 \mathrm{~cm}$ & $5-50 \mathrm{~cm}$ & $0-5 \mathrm{~cm}$ & $5-50 \mathrm{~cm}$ & value & value \\
\hline SOC $\left(\mathrm{tC}\right.$ ha $\left.^{-1}\right)$ & $4.15 \pm 0.39^{a}$ & $4.91 \pm 0.30^{\mathrm{a}}$ & $4.50 \pm 0.29^{a}$ & $4.64 \pm 0.31^{\mathrm{a}}$ & $0.54 \pm 0.04^{c}$ & $3.03 \pm 0.17^{b}$ & 36.69 & 0.001 \\
\hline $\mathrm{C} / \mathrm{N}$ & $12.93 \pm 0.65^{a}$ & $2.48 \pm 0.28^{c d}$ & $10.66 \pm 1.03^{b}$ & $2.30 \pm 0.39^{\mathrm{cd}}$ & $3.56 \pm 0.45^{c}$ & $1.42 \pm 0.11^{\mathrm{d}}$ & 74.34 & 0.001 \\
\hline
\end{tabular}


higher at both soil depths compared to the control dune. The lowest soil $\mathrm{K}$ was observed in the control dunes for both depths as afforestation resulted in a significant increase in soil $K$ (Tab. 1). Although the soil $\mathrm{N}$ values in studied sites were low, afforestation led to significant soil $\mathrm{N}$ increase in topsoil $(0-5 \mathrm{~cm})$ compared to the control dunes, with $>75 \%$ canopy coverage sites having the highest $\mathrm{N}$ levels in topsoil. In deeper soil depth, no significant difference was observed between afforestation and control dunes (Tab. 1).

\section{Soil C stock in afforested and control dunes}

Topsoil C stock (SOC) showed an increasing trend from 0.54 to $4.50 \mathrm{tC} \mathrm{ha}^{-1}$ in control to afforestation dunes (Tab. 2). Despite the significantly higher carbon stock in afforested areas, no significant differences were observed between the two canopy classes (Tab. 2). The same SOC patterns related to afforestation were observed at the deeper soil depth and no significant difference was observed between the soil depths studied in afforested dunes (Tab. 2).

The lowest $\mathrm{C} / \mathrm{N}$ ratio belonged to the subsoil $(5-50 \mathrm{~cm})$ in control dunes, and the highest value belonged to topsoil in the 25$50 \%$ canopy class (Tab. 2). Furthermore, the $\mathrm{C} / \mathrm{N}$ ratio decreased with soil depth in both afforestation and control sites (Tab. 2).

The soil pH and sand content in topsoil showed significant negative correlations with $C$ stock, while positive correlations between soil $C$ stock and all other studied parameters were observed. (Tab. 3).

Considering the significant correlations between soil silt and the rest of soil parameters, $\mathrm{C} / \mathrm{N}$ and silt were important in determining soil physico-chemical properties of sand dunes in topsoil (Tab. 3 ).

Unlike the topsoil, soil $C$ stock in subsoil significantly correlated with only soil $\mathrm{P}, \mathrm{EC}$ and $\mathrm{C} / \mathrm{N}$ ratio. Additionally, $\mathrm{C} / \mathrm{N}$ ratio was positively and significantly correlated with soil EC and silt and negatively with soil $\mathrm{N}$ and sand (Tab. 4).

\section{Discussion}

Afforestation with $P$. juliflora increased soil $\mathrm{C}$ content to a depth $50 \mathrm{~cm}$ compared to control dunes. This is consistent with predictions for nitrogen fixing trees like $P$. juliflora (Resh et al. 2002), and with the results of Hu et al. (2015).

Although canopy coverage class did not have any significant effect on soil $C$ stock, our results showed a slight increase in soil $C$ stock with higher canopy coverage. This pattern is consistent with Schulp et al. (2008) who stated the importance of overstory on soil carbon input. Overstory can change light penetration and moisture content (Buck \& St Clair 2012), which can in turn affect soil $C$ stock (Dorfer et al. 2013). Additionally, tree spacing and canopy closure influence temperature, moisture, lit-

Tab. 4 - Correlations between soil carbon stock, $\mathrm{C} / \mathrm{N}$ and soil physico-chemical properties at 5-50 cm soil depth. $\left(^{*}\right): p<0.05$ (2-tailed); $(* *): p<0.01$ (2-tailed).

\begin{tabular}{|c|c|c|c|c|c|c|c|c|c|}
\hline Soil property & SOC & $\mathrm{C} / \mathrm{N}$ & Silt & Sand & EC & $\mathrm{pH}$ & $\mathbf{P}$ & K & $\mathrm{N}$ \\
\hline SOC $\left(\mathrm{tC}^{-h^{-1}}\right)$ & 1 & - & - & - & - & - & - & - & - \\
\hline $\mathrm{C} / \mathrm{N}$ & $0.35^{*}$ & 1 & - & - & - & - & - & - & - \\
\hline Silt (\%) & 0.03 & $0.31^{*}$ & 1 & - & - & - & - & - & - \\
\hline Sand (\%) & -0.03 & $-0.31^{*}$ & $-1.00^{* *}$ & 1 & - & - & - & - & - \\
\hline$E C\left(\mathrm{~d} \mathrm{~s} \mathrm{~m}^{-1}\right)$ & $0.38^{*}$ & $0.40^{* *}$ & $-0.30^{*}$ & $0.30^{*}$ & 1 & - & - & - & - \\
\hline $\mathrm{pH}$ & -0.27 & -0.17 & 0.17 & -0.17 & -0.26 & 1 & - & - & - \\
\hline $\mathrm{P}(\mathrm{ppm})$ & $0.38^{* *}$ & 0.09 & $-0.54^{* *}$ & $0.54^{* *}$ & $0.72^{* *}$ & -0.16 & 1 & . & - \\
\hline $\mathrm{K}(\mathrm{ppm})$ & 0.25 & 0.03 & -0.03 & 0.03 & 0.24 & -0.01 & 0.27 & 1 & - \\
\hline N (\%) & 0.24 & $-0.56^{* *}$ & $-0.37^{*}$ & $0.37^{*}$ & 0.01 & -0.01 & $0.33^{*}$ & $0.30^{*}$ & 1 \\
\hline
\end{tabular}

Tab. 3 - Correlations between soil carbon stock, $\mathrm{C} / \mathrm{N}$ and soil physico-chemical properties at $0-5 \mathrm{~cm}$ soil depth. ( $\mathrm{SOC}$ ): soil carbon stock ( $\mathrm{tC} \mathrm{ha-1)}$; (EC): electrical conductivity; $(P)$ : phosphorus; (K): potassium; $(N)$ : nitrogen; $(* *) p<0.01$ (2-tailed).

\begin{tabular}{|c|c|c|c|c|c|c|c|c|c|}
\hline Soil property & SOC & $\mathrm{C} / \mathrm{N}$ & Silt & Sand & EC & $\mathrm{pH}$ & $\mathbf{P}$ & $\mathrm{K}$ & $\mathrm{N}$ \\
\hline $\mathrm{SOC}\left(\mathrm{tC} \mathrm{ha}^{-1}\right)$ & 1 & - & - & - & - & - & - & - & - \\
\hline $\mathrm{C} / \mathrm{N}$ & $0.80^{* *}$ & 1 & - & - & - & - & - & - & - \\
\hline Silt (\%) & $0.71^{* *}$ & $0.54^{* *}$ & 1 & - & - & - & - & - & - \\
\hline Sand (\%) & $-0.71^{* *}$ & $-0.54^{* *}$ & $-1.00^{* *}$ & 1 & - & - & - & - & - \\
\hline$E C\left(\mathrm{~d} \mathrm{~s} \mathrm{~m}^{-1}\right)$ & $0.77^{* *}$ & $0.71^{* *}$ & $0.59^{* *}$ & $-0.59^{* *}$ & 1 & - & - & 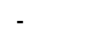 & - \\
\hline $\mathrm{pH}$ & $-0.72^{* *}$ & $-0.57^{* *}$ & $-0.54^{* *}$ & $0.54^{* *}$ & $-0.65^{* *}$ & 1 & - & - & - \\
\hline $\mathrm{P}(\mathrm{ppm})$ & $0.70^{* *}$ & $0.58^{* *}$ & $0.52^{* *}$ & $-0.52^{* *}$ & $0.73^{* *}$ & $-0.57^{* *}$ & 1 & - & - \\
\hline $\mathrm{K}(\mathrm{ppm})$ & $0.69^{* *}$ & $0.53^{* *}$ & $0.45^{* *}$ & $-0.49^{* *}$ & $0.70^{* *}$ & $-0.53^{* *}$ & $0.74^{* *}$ & 1 & - \\
\hline$N(\%)$ & $0.73^{* *}$ & 0.25 & $0.54^{* *}$ & $-0.54^{* *}$ & $0.54^{* *}$ & $-0.52^{* *}$ & $0.49^{* *}$ & $0.53^{* *}$ & 1 \\
\hline
\end{tabular}

ter, and consequently change decomposition rate and soil C stock (Paul et al. 2002).

As in Garcia-Franco et al. (2014), afforestation in the current study resulted in a higher soil $\mathrm{C} / \mathrm{N}$ ratio. Changes in soil $\mathrm{N}$ with change in land use from sand dunes to afforested area was also seen by $\mathrm{Li}$ et al. (2016a). Increased soil $\mathrm{N}$ in the sand dunes after afforestation is likely responsible for increasing soil carbon sequestration (Grunzweig et al. 2007). Higher $\mathrm{C} / \mathrm{N}$ ratio and also $C$ stock at the topsoil in sand dunes indicated the importance of this thin soil layer in $\mathrm{C}$ sequestration of arid lands ( $\mathrm{Na}$ dal-Romero et al. 2016).

Canopy coverage is known as an important factor influencing topsoil nutrients (Johnson et al. 2016). Significant effects of canopy coverage and litter input on soil $\mathrm{N}$ and $C$ have been previously observed in topsoil (Conti et al. 2016). This may be due to the higher litter fall in higher canopy coverage class (Arriaga \& Maya 2007). Similar results were observed in $\mathrm{EC}$ and $\mathrm{pH}$, indicating the significance of canopy coverage and afforestation on the parameters stated, which is consistent with the study of Naseri et al. (2012). Likewise, decrease in EC with soil depth was seen by $\mathrm{Li}$ et al. (2010).

Soil $K$ and $P$ were previously shown to be significantly affected by afforestation, with an increasing trend from bare to afforested dunes ( $\mathrm{Li}$ et al. 2016b). This might be related to the soil $\mathrm{pH}$ reduction providing better conditions for these two nutrients availability in soil (Moradi et al. 2015). Soil texture has been reported among the fac- tors strongly affecting the soil carbon dynamic (Paul et al. 2002). In our study, the soil silt and sand respectively had positive and negative correlations with soil C stock, which could be due to longer residence time of soil organic carbon in silt (Dobarco \& Van Miegroet 2014). Improvement of soil physico-chemical properties and soil C stock after two decades of afforestation demonstrates the remarkable importance of $P$. juliflora in the parameters studied and long term fixation of sand dunes.

Soil fertility and organic carbon were important factors on C stock in arid lands, as soil $C$ stock and physico-chemical properties highly correlated (Garcia-Franco et al. 2014). However, afforestation resulted into soil $\mathrm{pH}$ decreasing from alkaline toward neutral. Soil pH negatively affected on the $\mathrm{C}$ stock. Considering these two, we could conclude that soil $\mathrm{pH}$ declines after afforestation and prevents carbon loss to the atmosphere (Shi et al. 2012).

\section{Conclusion}

$P$. juliflora afforestation in sand dunes resulted in higher soil $C$ stock. Higher C stock in topsoil and high level of correlation between soil $C$ stock and almost all soil physico-chemical properties studied, especially in topsoil, indicated the importance of soil features in soil C stock of arid lands. Furthermore, canopy coverage is considered a factor affecting soil N, which consequently resulted in higher soil $\mathrm{C}$ stocks in sand dunes of Iran. 


\section{Acknowledgments}

We thank Behbahan Khatam, Alanbia University of Technology, Iran, for financial supporting this research work. Special thanks to Dr. David Showalter for his kind help in improving the English level of this work.

\section{References}

Arriaga L, Maya Y (2007). Spatial variability in decomposition rates in a desert scrub of Northwestern Mexico. Plant Ecology 189: 213-225. doi: 10.1007/s11258-006-9178-4

Amiraslani F, Dragovich D (2011). Combating desertification in Iran over the last 50 years: an overview of changing approaches. Journal of Environmental Management 92: 1-13. - doi: 10.10 16/j.jenvman.2010.08.012

Baldeck CA, Harms KE, Yavitt JB, John R, Turner BL, Valencia R, Navarrete H, Davies SJ, Chuyong GB, Kenfack D, Thomas DW, Madawala S, Gunatilleke N, Gunatilleke S, Bunyavejchewin S, Kiratiprayoon S, Yaacob A, Supardi MNN, Dalling JW (2013). Soil resources and topography shape local tree community structure in tropical forests. Proceedings of the Royal Society B: Biological Sciences 280 (1766): 2013054820130548. - doi: 10.1098/rspb.2013.0548

Bremer LL, Farley KL (2010). Does plantation forestry restore biodiversity or create green deserts? A synthesis of the effects of land-use transitions on plant species richness Biodiversity and Conservation 19: 3893-3915. - doi: 10.1007/s10531-010-9936-4

Bremner JM, Mulvaney CS (1982). Nitrogen total. In: "Method of Soil Analysis - Part 2. Chemical and Microbiological Methods ( $2^{\text {nd }}$ edn)" (Miller RH, Kieney DR eds), Agronomy Series no. 9, American Society for Agronomy and Soil Sciences, Madison, WI, USA, pp. 595-624.

Buck JR, St Clair SB (2012). Aspen increase soil moisture, nutrients, organic matter and respiration in Rocky Mountain forest communities. PLoS ONE 7 (12): e52369. - doi: 10.1371/journal. pone.0052369

Carreiras JMB, Pereira JMC, Pereira JS (2006). Estimation of tree canopy cover in evergreen oak woodlands using remote sensing. Forest Ecology and Management 223: 45-53. - doi: 10.1016/j.foreco.2005.10.056

Conti G, Kowaljow E, Baptist F, Rumpel C, Cuchietti A, Pérez Harguindeguy N, Díaz S (2016). Altered soil carbon dynamics under different land-use regimes in subtropical seasonally-dry forests of central Argentina. Plant and Soil 403: 375-387. - doi: 10.1007/s11104-016-2816-2

Dobarco RM, Van Miegroet H (2014). Soil organic carbon storage and stability in the aspenconifer ecotone in montane forests in Utah, USA. Forests 5 (4): 666-688. - doi: 10.3390/f504 0666

Dorfer C, Kuhn P, Baumann F, He J-S, Scholten T (2013). Soil organic carbon pools and stocks in permafrost-affected soils on the Tibetan Plateau. PLoS ONE 8 (2): e57024. - doi: 10.1371/jour nal.pone.0057024

Garcia-Franco N, Wiesmeier M, Goberna $M$, Martínez-Mena M, Albaladejo J (2014). Carbon dynamics after afforestation of semiarid shrublands: implications of site preparation techniques. Forest Ecology and Management 319:
107-115. - doi: 10.1016/j.foreco.2014.01.043

Grunzweig JM, Gelfand I, Fried Y, Yakir D (2007). Biogeochemical factors contributing to enhanced carbon storage following afforestation of a semi-arid shrubland. Biogeosciences 4: 891904. - doi: 10.5194/bg-4-891-2007

Houba VJG, Van Der Lee JJ, Novozamsky I (1995). Soil and plant analysis - a series of syllabi. Part 5b: Soil analysis procedures, other procedures. Department of Soil Science and Plant Nutrition, Wageningen Agricultural University, Wageningen, Netherlands, pp. 262.

Hu FL, Shou WK, Liu B, Liu ZM, Busso CA (2015). Species composition and diversity, and carbon stock in a dune ecosystem in the Horqin Sandy Land of northern China. Journal of Arid Land 7 (1): 82-93. - doi: 10.1007/s40333-014-0038-0 Jackson RB, Jobbágy EG, Avissar R, Roy SB, Barrett DJ, Cook CW, Farley KA, Maitre DC, McCarl BA, Murray BC (2005). Trading water for carbon with biological carbon sequestration. Science 310: 1944-7. - doi: 10.1126/science.1119282

Johnson BG, Verburg PSJ, Arnone JA (2016). Plant species effects on soil nutrients and chemistry in arid ecological zones. Oecologia 182: 299-317. - doi: 10.1007/s00442-016-3655-9 Jones MB, Donnelly A (2004). Carbon sequestration in temperate grassland ecosystems and the influence of management, climate and elevated $\mathrm{CO}_{2}$. New Phytologist 164: 423-439. - doi: 10.1111/j.1469-8137.2004.01201.x

Kahi CH, Ngugi RK, Mureithi SM, Ngethe JC (2009). The canopy effects of Prosopis juliflora (DC.) and Acacia tortilis (Hayne) trees on herbaceous plants species and soil physicochemical properties in Njemps flats, Kenya. Tropical and Subtropical Agroecosystems 10: 441-449. [online] URL: http://www.revista.ccba.uady.mx/ojs /index.php/TSA/article/view/97

Lal R (2004). Carbon sequestration in dryland ecosystems. Environmental Management 33: 528-544. - doi: 10.1007/s00267-003-9110-9

Li CH, Li Y, Xie JX, Tang LS (2007). Comparative on microbial community composition and microbial activities in desert and oasis soils. Acta Ecologica Sinica 27 (8): 3391-3399.

Li C, Li Y, Tang L (2010). Soil organic carbon stock and carbon efflux in deep soils of desert and oasis. Environmental Earth Sciences 60: 549557. - doi: 10.1007/s12665-009-0195-1

Li Y, Brandle J, Awada T, Chen Y, Hana J, Zhang $F$, Luo $Y$ (2013). Accumulation of carbon and nitrogen in the plant-soil system after afforestation of active sand dunes in China's Horqin Sandy Land. Agriculture, Ecosystems and Environment 177: 75-84. - doi: 10.1016/j.agee.2013. 06.007

Li C, Zhao L, Sun P, Zhao F, Kang D, Yang G, Han $X$, Feng $Y$, Ren $G$ (2016a). Deep Soil C, N, and P stocks and stoichiometry in response to land use patterns in the Loess Hilly Region of China. PLoS ONE 11 (7): e015907. - doi: 10.1371/jour nal.pone.0159075

Li XJ, Li XR, Wang XP, Yang HT (2016b). Changes in soil organic carbon fractions after afforestation with xerophytic shrubs in the Tengger Desert, northern China. European Journal of Soil Science 67: 184-195. - doi: 10.1111/ejss.12315 McLean EO (1982). Soil pH and lime requirement. In: "Methods of Soil Analysis, Part 2. Chemical and Microbiological Properties"
(Page AL, Miller RH, Keeney DR eds). American Society of Agronomy, SSSA, Madison, WI, USA, pp. 199-224.

Moradi M, Shirvany A, Matinizadeh M, Etemad V, Naji HR, Abdul-Hamid H, Sayah S (2015). Arbuscular mycorrhizal fungal symbiosis with Sorbus torminalis does not vary with soil nutrients and enzyme activities across different sites. iForest 8: 308-313. - doi: 10.3832/ifor1236-008

Morwin HD, Peach PM (1951). Exchangeability of soil potassium in and, silt and clay fractions as influenced by the nature of complementary exchangeable cations. Soil Science Society of America Journal 15: 125-128. - doi: 10.2136/sssaj 1951.036159950015000C0026x

Nadal-Romero E, Cammeraat E, Pérez-Cardiel E, Lasanta T (2016). Effects of secondary succession and afforestation practices on soil properties after cropland abandonment in humid Mediterranean mountain areas. Agriculture, Ecosystems and Environment 228: 91-100. - doi: 10.1016/j.agee.2016.05.003

Naseri S, Ali Adibi MA, Javadi SA, Jafari M, Zadbar M (2012). Investigation of the effect of biological stabilization practice on some soil parameters (North East of Iran). Journal of Rangeland Science 2 (4): 643-653.

Niu X, Gao P, Li Y, Li X (2015). Impact of different afforestation systems on soil organic carbon distribution characteristics of limestone mountains. Polish Journal of Environmental Studies 24 (6): 2543-2552. - doi: 10.15244/pjoes/59235 Olsen SR, Cole CV, Watanabe FS, Dean LA (1954). Estimation of available phosphorus in soils by extraction with sodium bicarbonate. USDA Circular 939: 1-19. [online] URL: http://krishikosh. egranth.ac.in/handle/1/2041713

Paul KI, Polglase PJ, Nyakuengama JG, Khanna PK (2002). Change in soil carbon following afforestation. Forest Ecology and Management 168: 241-257. - doi: 10.1016/S0378-1127(01)00740$\mathrm{X}$

Resh SC, Binkley D, Parrotta JA (2002). Greater soil carbon sequestration under nitrogen-fixing trees compared with Eucalyptus species. Ecosystems 5: 217-31. - doi: 10.1007/s10021-001-006 7-3

Sariyildiz T, Savaci G, Kravkaz IS (2015). Effects of tree species, stand age and land use change on soil carbon and nitrogen stock rates in northwestern Turkey. iForest 9: 165-170. - doi: 10.3832 /ifor1567-008

Schulp CJE, Nabuurs GJ, Verburg PH, De Waal RW (2008). Effect of tree species on carbon stocks in forest floor and mineral soil and implications for soil carbon inventories. Forest Ecology and Management 256: 482-490. - doi: 10.1016/j.foreco.2008.05.007

Shackleton RT, Le Maitre DC, Pasiecznik NM, Richardson DM (2014). Prosopis: a global assessment of the biogeography, benefits, impacts and management of one of the world's worst woody invasive plant taxa. AoB PLANTS 6: plu027. - doi: 10.1093/aobpla/plu027

Shi Z, Krom MD, Jickells TD, Bonneville S, Carslaw KS, Mihalopoulos N, Baker AR, Benning LG (2012). Impacts on iron solubility in the mineral dust by processes in the source region and the atmosphere: a review. Aeolian Research 5: 2142. - doi: 10.1016/j.aeolia.2012.03.001

Stringer CE, Trettin CC, Zarnoch SJ, Tang W 
(2015). Carbon stocks of mangroves within the Zambezi River Delta, Mozambique. Forest Ecology and Management 354: 139-148. - doi: 10.1016/j.foreco.2015.06.027

Walkley A, Black IA (1934). An examination of Degtjareff method for determining soil organic matter and a proposed modification of the chromic acid titration method. Soil Science 37: 29-37. - doi: 10.1097/00010694-193401000-000 03

Zhang YQ, Liu JB, Jia X, Qin SG (2013). Soil organic carbon accumulation in arid and semi- arid areas after afforestation: a meta-analysis. Polish Journal of Environmental Studies 22 (2): 611-620. [online] URL: http://or.nsfc.gov.cn/bit stream/00001903-5/233175/1/1000014170165.pdf 